\title{
Correction to: Articles in MCAP 23:1 March 2021 Issue to Be Classified as Original Articles
}

\author{
Joseph Glaz ${ }^{1}$
}

Published online: 15 May 2021

(C) Springer Science+Business Media, LLC, part of Springer Nature 2021

\section{Correction to: Methodology and Computing in Applied Probability (2021) 23:1. https://doi.org/10.1007/s11009-020-09833-7 https://doi.org/10.1007/s11009-020-09836-4 https://doi.org/10.1007/s11009-020-09838-2 https://doi.org/10.1007/s11009-020-09837-3}

The Publisher regrets an error by classifying an incorrect article type for the below-mentioned articles. These articles should be classified as "Original Articles".

- Foschi, R. Measuring Discrepancies Between Poisson and Exponential Hawkes Processes. Methodol Comput Appl Probab 23, 219-239 (2021). https://doi.org/10.1007/s11009-02009833-7

- Kim, J.J., Chaudhry, M.L., Goswami, V. et al. A New and Pragmatic Approach to the GIX/Geo/c/N Queues Using Roots. Methodol Comput Appl Probab 23, 273-289 (2021). https://doi.org/10.1007/s1 1009-020-09836-4

- Márkus, L., Kumar, A. Modelling Joint Behaviour of Asset Prices Using Stochastic Correlation. Methodol Comput Appl Probab 23, 341-354 (2021). https://doi.org/10. 1007/s11009-020-09838-2

\footnotetext{
The online version of the original article can be found at https://doi.org/10.1007/s11009-020-09833-7; https://doi.org/10.1007/s11009-020-09836-4; https://doi.org/10.1007/s11009-020-09838-2; https://doi.org/10.1007/s11009-020-09837-3
}

\section{Joseph Glaz}

joseph.glaz@uconn.edu

1 Department of Statistics, University of Connecticut, Storrs, CT, USA 
- Wu, Q., Glaz, J. Scan Statistics for Normal Data with Outliers. Methodol Comput Appl Probab 23, 429-458 (2021). https://doi.org/10.1007/s11009-020-09837-3

The original articles have been corrected.

Publisher's Note Springer Nature remains neutral with regard to jurisdictional claims in published maps and institutional affiliations. 